\title{
CHAPTER SIXTEEN
}

\section{SOPHOCLES}

\author{
I.J.F. DE JONG
}

\section{Introduction. Time awareness}

Time is of prime importance in tragedy: 'its subject matter is always one great event, which overthrows all that existed before: it means death, destruction, reversal of fortune; its strength rests on a contrast between before and after; and the deeper the contrast, the more tragic the event. That is why so many people, in tragedy, comment about time and its action. " ${ }^{\prime}$ Yet, speaking narratologically, time awareness is small: "Dramatists do not deal in "clock time" but in "dramatic time". In the hands of a good dramatist "clock time" can be compressed or expanded as required ... To facilitate their fluid treatment of time the Greek tragedians make sparing references to the time of day and its passing. There may be references to dawn or evening, "just now" or "soon" or "today"; but never in such a way as to invite the audience to consider precisely how long has elapsed between one part of the play and another.'2

Almost without exception the plot of Greek tragedies deals with one day in the lives of their main characters, a circumstance which Sophocles often thematizes: 'This day (hèe' hèmera) shall be your parent and

1 De Romilly i968: 5-6.

2 Taplin 1977: 290-294, quotation from 291-292. Other general studies on time in Sophocles include Morwood 1993 on the double time scheme in Antigone: short time (one day) versus long time (Creon is very much portrayed as someone who has already ruled for some time); Goward 1999 (prospective and retrospective narrative, time and the chorus); Hutchinson 1999 (the contrast between single, decisive, final events versus continuous states or repeated attempts); Heuner 200I (the relation between the 'objective' time structure and the 'subjective' time experience by the characters, and the linearity of the offstage time versus the discontinuity of the scenic time); Markantonatos 2002: 7-12 (time games within drama and the narratives of drama); Rehm 2003: II9-139. 
your destroyer', says Tiresias to Oedipus $\left(O T\right.$ 438). ${ }^{3}$ But whereas the plot concentrates on one day, the totality of events represented ${ }^{4}$ is much larger, and to include the past and future retrospective and prospective narratives are necessary. Since in the Studies of Ancient Greek Narrative the position is taken that a play is not a narrative, ${ }^{5}$ the terms 'retrospective' and 'prospective narrative' have been introduced to replace 'analepsis' and 'prolepsis'; the terms 'analepsis' and 'prolepsis' are, of course, regularly used in connection with anachronies within embedded narratives. Narratives also function within the plot itself, anticipating later scenes or recounting what happened offstage. The first aspect of time which merits our attention therefore is order.

\section{Order I: retrospective narratives}

The majority of dramatic narratives concern the past before the start of the play and therefore are external retrospective narratives. In all situations and at all places in the play characters may turn to the remote past; for example, 'O ride of Pelops long ago, bringer of many sorrows, how dire was your effect upon this land! For since Myrtilus fell asleep, plunged into the sea, hurled headlong from the golden chariot with cruel torment, never yet has the torment of many troubles departed from this house' $\left(E l .5^{0} 4^{-} 5^{1} 5\right)^{6}$

${ }^{3}$ Cf. Aj. 778-779; Tr. I66- I68; El. 674, 783-784; and cf. Schwindt I994.

${ }^{4}$ In drama-theory: the story. Drama-theory, notably Pfister [1977] I988: I97-I98, distinguishes between story (totality of events in chronological order) and plot (events in the form and order as they appear in the play), while the narratological model adopted in $S A G \mathcal{N}$ (and applied to the narratives embedded in drama) works with fabula and story $(\rightarrow$ Introduction), both distinctions basing themselves on the Russian formalist distinction between fabula and sjuzet. For an application of story-plot on Oedipus Tyrannus see M. Kraus 1994 (with apt criticism in Heuner 200I: 66). Pfister [1977] I988: 275-294 has a general discussion of aspects of time in drama.

${ }^{5}$ Cf. $S A G \mathcal{N}$ i:6-7 and Genette [1983] 1988: 'This restriction [of narratology to the analysis of narrative mode] seems to me on the whole legitimate, since the sole specificity of narrative lies in its mode and not its content, which can equally well accommodate itself to a 'representation' that is dramatic, graphic, or other. There are chains of actions or events amenable to any mode of representation - the story of Oedipus ... - and we call them 'narrative' only because we encounter them in a narrative presentation. This metonymic slippage is understandable but very ill advised. I would therefore readily argue ... for a strict use (that is, one referring to mode) not only of the (technical) term narratology, but also of the word narrative ...'.

${ }^{6}$ Other examples: Aj. 1293-1294, I295-1297; El. 837-847; Ant. 823-833, 944-987; Ph. 676-679. 
When we turn to the more recent past, the events which lead up to the plot of the play, it is characteristic of Sophocles not to present this prehistory in one block (as $\rightarrow$ Euripides does). ${ }^{7} \mathrm{He}$ may disclose elements of it at the opening of the play, as in the Antigone, where we hear (from Antigone) about $(\mathrm{C})$ Creon's edict forbidding the burial of Polynices issued the night before $(2 \mathrm{I}-36)$, (from Ismene) about (A) the fate of Oedipus and his sons in the past (49-57), and (from the chorus) about (B) the attack of the Seven against Thebes and the death of Eteocles and Polynices on the day before (I00-I47). But not seldom is crucial information about the past disclosed only at a very late stage, as when a messenger reports Calchas' revelation of Athena's wrath against Ajax (Aj. 748-783), which, finally, explains her vindictive behaviour towards him, about which we have heard and seen so much in the first part of the play. ${ }^{8}$ As Goward remarks, it is the task of the spectators to put together 'information given at different times during the course of the play and to create a sequential narrative' (of what happened in the past preceding the play). ${ }^{9}$

Sometimes it is not so much the spectators as the characters who have to piece together the past, and the prime example here is of course the Oedipus Tyrannus, which has been aptly called an 'Enthüllungsdrama' and detective story. ${ }^{10}$ Put in chronological order the prehistory of the Oedipus Tyrannus is as follows: (A) Laius receives an oracle that he will be killed by his son-(B) he exposes Oedipus, who is, however, handed over by a Theban servant to a Corinthian herdsman, who brings the child to the Corinthian royal couple-(C) Oedipus receives an oracle that he will kill his father and marry his mother-(D) he kills Laius - (E) defeats the Sphinx - and (F) marries Jocasta.

In the actual play, however, this narrative is fragmented into bits and pieces, smaller and larger retrospective narratives, which are recounted by different characters and in anachronical order. It starts with a

${ }^{7}$ Cf. Arist. Rh. I415ar8-20; Reinhardt [1933] I943: 47; Hulton r969: 53; H.W. Schmidt 1971: 27; Gellie 1972: 193; Roberts 1989: г6г.

${ }^{8}$ Cf. Winnington-Ingram I980: $39-43$, who also draws attention to the crucial depiction of Ajax in the past (before the contest and his madness) which Calchas' going back in time provides. Other examples: $T r$. 555-58I (how Deanira got the poison from Nessus), II59-II7I (a prophecy and oracle about Heracles' death). Oedipus' curse of his sons $\left(O C{ }_{1} 3^{8} 5^{-1} 3^{88}\right)$ is taken by most scholars to refer to his words in $4{ }^{12-} 427$ and is therefore no external retrospective narrative.

${ }^{9}$ Goward I999: 21.

10 Cf. Schadewaldt i97o: 466-476; Flashar i976; and Heuner 2001: 65-102. 
reference to (E) the Sphinx, thus marking the height of Oedipus' glory (35-39). An oracle brought back by Creon then introduces the central event of the play, (D) the murder of king Laius (IO3-I3I, repeated by the chorus in 290-292). The seer Tiresias is the first to reveal that (D') Oedipus is the murderer of Laius $(353,362)$; indeed, prodded on by a disbelieving and hostile Oedipus, he even refers, in riddling terms, to the facts that he (D") killed his father and (F) married his mother (449454). Dismayed, Oedipus himself once more clings to (E') his glorious defeat of the Sphinx (39I-398). Wanting to comfort Oedipus Jocasta tells him about (A) the oracle to Laius and (B) the exposure of their child (707-725), and argues that the oracle is disproved by (D"') Laius' death by robbers instead of his son $\left(726-75^{6}\right)$. However, stirred by one word in her brief report on Laius' death, Oedipus now recounts to her $(\mathrm{C})$ the oracle he once received and ( $\mathrm{D}^{\text {"', })}$ his murder of a man in circumstances similar to those of Laius as reported by Jocasta (77 I832). Oedipus now very much fears that indeed he killed Laius, but neither he nor Jocasta makes a connection with the two oracles (A and C) yet. Indeed, these seem disproved by the arrival of a messenger from Corinth, who reports the death of the king, Oedipus' 'father'. Wanting to reassure Oedipus, he informs him how $(B)$ he once received him as a baby from a Theban servant (I008-I053). Jocasta now understands the truth of what happened and after vainly trying to stop Oedipus from investigating his past any further she leaves the stage. At this point the eyewitness of Laius' murder enters, who, recognized by the Corinthian messenger, reluctantly confirms (B') how he once handed over the child he had been ordered to expose (II2I-II8I). Now Oedipus' moment of complete insight has come (II84-II85).

Scholars have remarked that this whole process of Oedipus finding out the truth about himself is not realistic, in that it is unlikely that husband and wife did not discuss the past before. In dramatic and narratological terms, however, this is a highly effective structure: the direction of the retrospective narratives is regressive, moving from a more recent past to the remote past: Oedipus begins his search with the question of his murder of Laius but ends with his birth and the even more vital point of his identity. In employing this technique of the 'piecemeal presentation' of a narrative Sophocles is clearly indebted to Homer $(\rightarrow)$, who exploited it to great effect, for example when making different characters in the Odyssey talk about Odysseus' return.

Apart from presenting the prehistory of the plot in a series of fragmented retrospective narratives, Sophocles may also reveal one and the 
same element of the plot's prehistory gradually, in the form of repeating narratives told by different characters. An example is Ajax' mad nocturnal onslaught on the herds. ${ }^{11}$ The first to tell us about it is Odysseus ( $A j$. I8-33), who is still trying to find out what has happened. The only thing he knows (from his own observation) is that animals have been slaughtered and (from a scout) that Ajax has been seen running through the fields in the night. Next, Odysseus is informed by Athena (36-65) that it was indeed Ajax who killed the beasts and that he is presently torturing other animals in his tent. She also tells him why Ajax has started on his expedition in the first place (he is angry because he had not been awarded Achilles' armour) and that, struck with madness by herself, he thinks that he is revenging himself on the Greek generals. This is then confirmed in a dialogue between the goddess and Ajax himself, with Odysseus as witness (9I-II7). Then the chorus enters, which, having only heard rumours, speculates about which god made Ajax do this and is still hopeful that it will all turn out not to be true (I4I-I47, I72-I85). Their fears are confirmed, however, by Tecmessa (2I4-220, 233-244, 284-327), who tells how Ajax left their tent in the middle of the night, sword in hand, came back to torture animals inside the tent, until, finally, he came to his senses and realised what he had done. By this time the spectators are fully informed about all the different stages of Ajax' action, the divine machinery behind it, and the perspectives on it of the main persons involved. ${ }^{12}$

Sophocles is particularly wont to use the device of the 'piecemeal presentation' in connection with oracles and prophecies. Their content is never quoted verbatim (as it usually is in, for example, Herodotus) but revealed only gradually, via the potentially distorting focalization of mortal characters. An example is the oracle concerning Philoctetes in the Philoctetes, which seems to change every time it is mentioned. However, when we allow for each character to have his own reasons for relating it, a reasonably consistent and dramatically effective picture emerges. ${ }^{13}$ In the prologue Odysseus tells Neoptolemus that with-

\footnotetext{
11 Cf. Segal i989-ig9o and de Jong 2005.

12 Other examples of piecemeal distribution: the murder of Laius $\left(O T_{\text {IO3-I3I, } 290-}\right.$ 293, 359, 558-569, 707-862); Heracles' sack of Oechalia (Tr. I80-I99, 229-290, 335374, 395-489; cf. $S A G \mathcal{N}$ I:259); and the quarrel between Eteocles and Polynices $(O C$ $324-420,42 \mathrm{I}-454, \mathrm{I} 29 \mathrm{I}-\mathrm{I} 325)$.

13 Cf. (too strongly) T. Wilamowitz i9ı7: 20 ('Die dramatische Wirkung der einzelnen Szene steht ihm ... höher als die einheitliche Anlage der Fabel, und er rechnet damit,
} 
out Philoctetes' bow he will not be able to capture Troy (68-69). He does not mention any oracle, and Neoptolemus' asking how he is to proceed (why not by force or persuasion, but by deceit?, 86-III) and his surprise, indeed disappointment, at hearing that something else apart from himself is necessary for the fall of Troy (I I4) imply that the youth is ignorant of its exact form, perhaps even of its very existence. This ignorance allows Odysseus to lay stress on the bow rather than the man (Philoctetes), thus somewhat sweetening the bitter pill for the young hero that he is not the sole captor of Troy. In his lying tale to Philoctetes, in which he pretends to return to Greece and which is aimed at luring Philoctetes into coming with him (343-390), Neoptolemus does not refer to any divine order that Philoctetes should go to Troy.

It is only in the lying tale of the 'Merchant', which is aimed at making Philoctetes even more eager to join Neoptolemus by telling him that Odysseus and Diomedes are after him (570-62I), that the oracle is introduced for the first time: it derives from the Trojan Helenus and prescribes that Philoctetes (and his bow) is to be brought to Troy by persuasion (610-613). At this stage, the recounting of the oracle seems not so much aimed at Philoctetes, who is only infuriated by the idea of being persuaded by his enemies (622-638), as at Neoptolemus, who ought to become even more convinced that the cause he is fighting for is a just one. When at the end of the play Neoptolemus, though having confessed his deceit and having given back the bow, is making a last effort - by persuasion - to make Philoctetes come with him to Troy, he himself once more recounts the oracle (1329-1342). This report is now fully aimed at Philoctetes and hence for the first time mentions that when coming to Troy he will be cured. However, even in its full and attractive form the oracle does not persuade Philoctetes. It is only the authority of Heracles which finally makes him decide to go to Troy: Heracles confirms the oracle in a prospective narrative which reveals that Philoctetes will be cured, kill Paris, and destroy Troy together with Neoptolemus and with the help of his bow. Only once in the course of this protracted revelation of the terms of the oracle is Sophocles using a sleight-of-hand or is perhaps even making a minor slip: when he makes Neoptolemus, who at the beginning of the play did not seem to know

dass, da das jedesmal vor Augen des Zuschauers wirklich Geschehende so zur stärksten Wirkung kommt, die ... Inkongruenz nicht bemerkt wird'); more appreciatively Hinds I967 and Easterling 1978. 
about the oracle at all (or only vaguely), recite it to Philoctetes very knowledgeably ('There is a man with us ..., Helenus, who tells us...'). ${ }^{14}$

The large number and deft handling of retrospective narratives dealing with the prehistory of plays has by now become clear. How about internal retrospective narratives? A large group is taken up by narratives recording events which have just taken place offstage, mainly messenger-speeches (e.g. the death of Jocasta, OT I237-I285), but also other types of narratives (e.g. the miracle with the tuft of wool, which makes Deanira realize her fatal mistake in sending Heracles the robe anointed with the unguent she got from the centaur Nessus, Tr. 672722). ${ }^{15}$ The close connection with the time of the onstage action is made clear by means of adverbs of time ('just now', 'recently') and the frequent opening of these narratives with the temporal conjunction epei, which indicates that they pick up from an earlier point in the play (thus, when the messenger in Oedipus Tyrannus starts his narrative with 'When frantic she [Jocasta] had passed within the vestibule, she rushed straight towards her nuptial couch...', he picks up from the moment when in I072 Jocasta left the stage, an act described by the chorus as: 'Why did the woman, Oedipus, leave hurried by a wild grief ?'). ${ }^{16}$

The fact that so much of the action of Greek tragedy is relegated to the offstage area and hence has to be reported to the spectators in the form of narrative can be explained by the central role of the chorus, which - almost without exception - remains onstage during the entire play and thereby precludes changes of place. But the interplay of onstage action and offstage narrative also has a dynamic and significance of its own: by the time they reach the stage the events reported have already taken place and therefore cannot be changed or influenced any more by those onstage. This is well illustrated by the two

14 Other examples: the oracle concerning Heracles in Trachiniae, for which see Gellie I972: 69; Heiden ı989: 34-36; C. Kraus ı991: 82-83; and Segal 20oo; Apollo's prophecy to Orestes in Electra, for which see L. Macleod 2001: 28-38; the oracle to Laius in Oedipus Tyrannus, for which see Heuner 2001: 74-76; the oracles concerning Oedipus in Oedipus Coloneus.

15 For the corpus of messenger-speeches see $S A G \mathcal{N}$ I:26r n. 20. Other offstage reports: $E l$. 4I7-427 (the dream of Clytemnestra), 882-9i9 (Chrysothemis finding Orestes' hairlock); Ant. 998-ro32 (the omens which Tiresias saw). It should be noted, however, that not all offstage reports are strictly speaking internal; the false stories about Orestes' death (El. 680-763) and Odysseus' mission to get Philoctetes (Ph. 6o362I) refer to events which largely precede the starting point of the plot.

16 See for this interpretation of epei at the opening of messenger-speeches Rijksbaron I976. 
burials of Polynices in the Antigone (249-277 and 407-440): the first messenger-speech confronts Creon with the fact that his edict has been violated on the very first day it was issued, the second with the even worse fact that it has been violated (again) by, as has become clear now, a woman. ${ }^{17}$

Another, smaller group of internal retrospective narratives derives from characters who look back on their own or other people's deeds performed in the play. An example is Creon's remorseful confession that his decisions have been totally mistaken and disastrous (Ant. I26 II275), which contains the tragic keywords hamartemmata 'tragic errors' and mathōn deilaios 'learning at one's cost'. ${ }^{18}$

\section{Order 2: prospective narratives}

Just as dramatic characters are often recalling or reflecting on the past, much of their energy is taken by - anxious or confidentialanticipation of the future. Not all of these anticipations are narrative (they may be short announcements or orders or the like), but occasionally we do have real prospective narratives. ${ }^{19}$ Often they concern the impending ruin of the main characters, as when Tiresias announces to Oedipus 'that he shall be revealed to be a native Theban, that he shall travel over strange land blind instead of seeing, and that he shall be revealed both a brother and a father to his children, both a son and a husband to his wife, and both a sharer in his wife and a killer to his father' (OT 452-46o; cf. earlier 417-425); the outcome will follow in I287ff. and after the play. ${ }^{20}$

Prospective narratives will naturally tend to employ prior narration, as in the example just given ('Oedipus shall be revealed'), but they may also take the form of subsequent narration, as in the case of Chrysothemis' report to Electra of Clytemnestra's dream: 'They say

\footnotetext{
${ }^{17}$ Heuner 200I, for the Antigone esp. IO-I2 and 24-25. For other interpretations of the doubling of burial and report see Scodel 1984 (where older interpretations).

18 Other examples: $A j$. I383-1 388 (Teucer looks back on Odysseus' consistently noble behaviour versus Ajax); Ph. I228 (Neoptolemus looks back on his deceit of Philoctetes); Tr. III4-II42 (Hyllus looks back on Deanira's fatal error with the poisoned cloak; note hèmarten, hamartèmenos 'having committed a tragic error').

${ }^{19}$ Cf. Goward 1999: 25-26.

${ }^{20}$ Other examples: Tr. 705-722 (deaths of Deanira and Heracles); Ant. Io64-1086 (ruin of Creon); a positive prospective narrative: Ph. I325-I335 (Neoptolemus tells Philoctetes what will happen to him if he comes to Troy).
} 
that she was once more in company with your father and mine, who had come to the world of light; and then he took the staff which he used to carry, and which Aegisthus carries now, and planted it beside the hearth; and from it grew up a fruitful bough, which overshadowed all the land of the Mycenaeans' (El. 4I7-423). The dream is told in the form of subsequent narration, but has the function of a prospective narrative, announcing the return and revenge of Orestes. This prospective function becomes explicit in Electra's interpretation of the dream: 'Abandon these [Clytemnestra's libations], and cut locks from your hair ... Kneel and pray him to come in kindness from below the earth to help us against our enemies, and pray that his son Orestes may get the upper hand and may trample, alive and well, upon his enemies... I believe, yes, I believe that it is he who was concerned to send these ugly dreams to her.'21 Sophocles' frequent use of dreams, prophecies, and omens ${ }^{22}$ as prospective narratives for the spectators but ambivalent signs for the characters involved resembles Homer $(\rightarrow)$ and Herodotus $(\rightarrow)$.

A special case of prospective narrative is Oedipus Coloneus ro44-I055, where the chorus imagines the coming battle between Thebans and Athenians; this prospective choral narrative thereby replaces a retrospective messenger-speech. But it is not a matter of mere replacement: since the chorus is only imagining the battle, their narrative displays an effective mixture of the hypothetical ('I think', I054, I059; 'either ... or', I058I059, I074), the self-confident ('Creon shall be taken', I065; 'I predict a victory in the battle', Io6o), and the subjective ('Zeus grant to the guardians of the land's people to seize the prey with victorious might', I085-I089). ${ }^{23}$

Prospective narratives are also used in the context of guile and deceit, as in Electra 39-66, when Orestes sketches to the old pedagogue (and Pylades) how they must proceed to carry out Apollo's oracle and take revenge on behalf of his father: 'Do you go into this palace... and find out everything that they are doing, so that you can report to

\footnotetext{
${ }^{21}$ For Clytemnestra's dream see Bowman 1997. Another example is Tiresias' report to Creon on the negative omen he received (Ant. 998-Ior3), followed by his interpretation (Io64-I086), which in the form of a prospective narrative announces Creon's doom: 'Then know well that you shall not accomplish many racing courses of the sun ...'?

${ }^{22}$ Cf. the omens in Trachiniae, Oedipus Tyrannus, Oedipus Coloneus; the prophecies in Philoctetes, Antigone.

${ }^{23}$ Cf. Gellie I972: I79; Burton I980: 280-284; Goward 1999: 23; and Markantonatos 2002: 100-108.
} 
us with certain knowledge. They will never know you, grizzled as you are with age and the passage of time, and they will not suspect you. Tell this story, that you are a foreigner who has come from Phanoteus the Phocian ... and tell them, speaking on oath, that Orestes is dead by an accident, having fallen from his moving chariot in the Pythian games; let that be your tale. And we will first honour my father's tomb ... then we will return once more, carrying in our hands the bronze urn ... so that we can deceive them with our words and bring them happy news, that my body has already been burnt to ashes. ${ }^{24}$ The effectuation of the scheme follows onstage (from 66o onwards), including the false narrative here synoptically announced (68o-763). This structure, plotting followed by effectuation, will become a staple ingredient of the Euripidean $(\rightarrow)$ mechanema-plays, though there the effectuation usually takes place offstage and is reported by a messenger.

Just as Sophocles is the master of the false retrospective tale, he is also fond of inserting hypothetical, eventually not effected, or even downright false prospective narratives. ${ }^{25}$ An example of a hypothetical prospective narrative is Teucer imagining how his father will welcome him, now that he has not been able to save his brother Ajax: 'Smiling and kindly, I imagine, will be my welcome from Telamon, your father and also mine, when I come home there without you. Of course, seeing that even when fortune is good it is not his way to smile more graciously. What will he keep back? What evil will he not speak of me, the bastard born of the prize he won in battle, the betrayer, in my cowardice and weakness, of you, dearest Ajax, or in my cunning. So that with you dead I might control your lordship and your house? Such words will be uttered by a man who is irascible, fierce in old age, and quick to quarrel angrily over nothing. In the end I shall be rejected and cast out from the land, denounced as a slave, no longer a free man' ( $A j$. I008-IO2I). As so often in Sophocles, words have a double meaning: this hypothetical prospective narrative is in the first place expressive of Teucer's own present feelings of remorse and failure, but the spectators know that, according to tradition, Teucer indeed was to be banished by Telamon (and to found Salamis on Cyprus). ${ }^{26}$

\footnotetext{
${ }^{24}$ Another example is Philoctetes 54-69, when Odysseus tells Neoptolemus how to approach Philoctetes, tell him a false tale about himself and thus lure him into coming with him.

${ }^{25}$ Cf. SAGN I:266-267. Goward I999: 87-i 8 discusses both retrospective and prospective false narratives.

26 Other examples: Aj. 460-47o (Ajax' future after his disgraceful attack on the
} 
An example of a prospective narrative which in the end is not fulfilled is Antigone 773-780: Creon announces that he will bury Antigone alive and let her slowly die of starvation, but in II92-1243 a messenger reports that she committed suicide. The effect of inserting this prospective narrative is to underscore Creon's - ever increasing - loss of control in this play.

The obvious - though far from uncontroversial - example of a false prospective narrative is Ajax' announcement that he will bury his sword and give up his wrath against the Greek generals (Aj. 654-692). What complicates the matter here is that this narrative has a double function: for Ajax' intradramatic narratees, Tecmessa and the chorus, it is meant to be true, whereas Sophocles suggests the extradramatic narratees, the spectators and later readers, enough hints to see that this prospective narrative, though showing us an Ajax toying with the idea of reconciliation and sincerely pitying Tecmessa, is false (e.g. his going to the washing-places, loutra, suggests the washing of a corpse before burial; his going to the meadows near the shore means a return to the scene of his 'crime'; his reference to hiding his sword and Hades keeping the sword below suggest his own burial together with his sword; and his 'going where he must journey' conjures up the last journey, to death). ${ }^{27}$

The prospective narratives discussed so far are largely internal and only very occasionally refer to a future outside the plays. In the same way it is characteristic of Sophocles not to end his plays with prolonged external prospective narratives, as Euripides $(\rightarrow)$ does, revealing what the future has in store for his dramatic heroes. ${ }^{28}$ However, scholars have pointed out brief passages or remarks which seem to allude to the future outside the play and to other texts. ${ }^{29}$ An example is the prediction which Tiresias makes to Creon in Antigone 1080-I084: 'all the cities [which participated in the expedition of the Seven against Thebes] are stirred up by enmity, from which the mangled bodies have

herds), 496-505 (Tecmessa's fate after Ajax' death); and El. 973-985 (Electra's prospective narrative of the fame she and Chrysothemis are going to win when they kill Aegisthus).

${ }^{27}$ For a discussion of the many interpretations proposed see Garvie 1998: I84-I86, to which should now be added Goward I999: 88-91 and Lardinois 2005.

28 The topic of the closure of Sophoclean drama concerns the handling of time in general (not of the narrative parts) and therefore lies outside the scope of this chapter. For discussions see Kremer 1971; Roberts 1988; Segal 1996; and Goward 1999: 49-52.

${ }^{29}$ Other examples: Tr. I270-I271; OT I455-I457; El. I497-I498; Ph. I440-I44I; OC I769-I772. Cf. esp. Roberts I988, with more scholarship. 
been consecrated by dogs or beasts, or some winged bird, carrying the unholy scent to the city with its hearts'. Hearing this, the spectators may have been reminded of the Athenian expedition led by Theseus to recover the bodies for burial and perhaps the later expedition of the victorious Epigoni, themes dealt with in other plays.

\section{Order 3: chronological versus anachronical}

From the temporal relationship between dramatic narratives and the plot of the plays in which they are embedded, this section turns to the order within narratives. The normal order is chronological, as is best illustrated by the group of long, continuous narratives in Sophocles: the messenger-speeches. Thus, Hyllus, reporting the poisoning of Heracles (Tr. 749-8I2), proceeds as follows: he met his father when he was sacrificing on Mt Ceneaum - then Lichas arrived, who gave Heracles the (poisoned) cloak of Deanira - the poison started to work-Heracles interviewed Lichas and then killed him-Heracles, suffering more and more, asked Hyllus to take him home-he will arrive soon.

Since they recount the events as they experienced them at the time, Sophoclean messengers only sparingly use analepses or prolepses, just like Euripidean $(\rightarrow)$ messengers. Only occasionally-but effectivelydo they insert an actorial analepsis, for example when the messenger in the Ajax quotes (in indirect speech) Calchas' account of Ajax' two instances of hubristic behaviour and words in the past (762-770a, 77ob775), which brought him Athena's anger, ${ }^{30}$ or a narratorial prolepsis, when the messenger in Electra says, halfway his (false) narrative of Orestes' death at the Pythian games, 'So far, things stood thus; but when one of the gods does mischief, not even a mighty man can escape' $(696-697){ }^{31}$

In the dialogical narratives, however, the order is often anachronical, being determined by the interplay of question and answer. An example is the dialogue between Oedipus and the chorus in Oedipus Coloneus 5 ${ }^{\mathrm{IO}-}$ 548 , in which his past is reviewed, first $(\mathrm{C})$ his marriage to his mother and $(\mathrm{D})$ the birth of two daughters, then (B) his defeat of the Sphinx, and finally (A) the killing of his father.

\footnotetext{
${ }^{30}$ Cf. OT I246-I250 (messenger reports Jocasta's reminiscences).

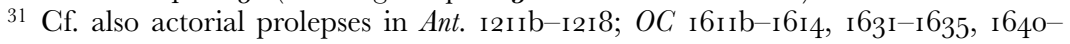
I644.
} 
Occasionally we find, both in continuous and dialogical narratives, the device of the 'epic regression' ( $\rightarrow$ Homer, $\rightarrow$ Pindar), which means that a narrator goes back in time step by step and then having reached the most remote event proceeds forward again. An example is Lichas' (partly false) report to Deanira on Heracles' prolonged absence (Tr. 248-290):32 (C) Heracles was sold by Eurytus as a slave to the Lydian queen Omphale and (D) upon his release sacked Oechalia by way of revenge (248-26oa) - (A) Eurytus had insulted Heracles (26ob-269a)(B) who in turn killed Eurytus' son Iphitus (269b-273) - (C') on account of this Zeus has him sold to the Lydians $\left(274^{-280}\right.$ - - (D') the city of Oechalia is sacked by Heracles (28I-285). This order is both natural in that Lichas starts by correcting Deanira's idea that sacking Oechalia took Heracles so long ('No, he was first detained for a year in Lydia ...') and then proceeds to tell her the story from the start, and at the same time highly effective, since all stress is put on Heracles' revenge on Eurytus as the motive for sacking Oechalia, while his real motive, infatuation for Iole, is suppressed.

\section{Rhythm}

Tragic narratives are rather short by epic, historiographical, or novelistic standards (at most some hundred lines), but they nevertheless make effective use of differences in speed. The main distinction is the one between summary and scene. Mythological tales or events of the remote past are usually recounted in the form of summaries, while messenger-speeches and related continuous reports of personal experiences tend to include scenic passages.

Summary and scene can also be combined, as is usually the case in messenger-scenes, where in the dialogue preceding his report the messenger first reveals very briefly his main news and then, being asked for more information, turns to a more detailed report. An example is Oedipus Coloneus 1579-1585: '[messenger] Men of the city, the briefest way to tell my news would be to say that Oedipus is dead! But to tell in few words what happened neither the words nor the actions that took

${ }^{32}$ I base myself on Halleran 1986, who also refers to the way in which this narrative itself, with its untraditional emphasis on Zeus punishing Heracles for his stealthy murder of Iphitus, anticipates Deanira's stealthy murder of Heracles. Other examples of epic regression: Aj. 21-33; El. 404-427; and Tr. 555-581. 
place there permit. [chorus] Is the poor man dead indeed? [messenger] Be assured that that man has left our ordinary life! [chorus] How did it happen? Did the poor man die in a god-sent and painless fashion?' The same structure of brief announcement followed by a request for more information is found in the messenger-scenes of Euripides $(\rightarrow)$; one is also reminded of the device of the 'header' (found from $\rightarrow$ Homer onwards) or 'initial summary with subsequent elaboration' found in Pindar $(\rightarrow)$ and Bacchylides $(\rightarrow)$.

In the course of the messenger's narrative the rhythm also modulates, for example in the case of Electra 680-763. The pedagogue starts his (false) tale of Orestes' death in summary style (in the days preceding his fatal accident Orestes won all contests of the Pythian games in which he participated, 68I-697), to which he himself draws attention: 'And to speak briefly, when there is much to tell' (688). Then he turns to a very scenic report of the fatal race-course which ends with Orestes' death (698-756): he includes the names of all the participants, the colour of their horses, and the exact details of Orestes' grooming of his horses (at first he gives his right-hand horse room every time he makes his turn around the post and only grazes it, but the last time he relaxes his left-hand rein and thereby strikes the post and breaks his axle). After the youth's fatal accident, he wraps up his story very quickly, dismissing Orestes' burial in half a verse (757a).

This particular pattern is not difficult to account for: evoking the initial series of Orestes' successes increases the impact of his later death; turning to a very detailed eyewitness report in the middle adds to the authority of what in fact is a purely invented tale; and having reached the goal of his story (Orestes is dead), he hurries on to the present, the imminent arrival of some Phocians with Orestes' ashes. Though being highly scenic, this messenger-speech does not contain any direct speech. Indeed, unlike Euripidean $(\rightarrow)$ messengerspeeches, which invariably contain direct speeches (as well as indirect ones), Sophoclean messenger-speeches may contain speeches (notably Aj. 284-327 and 748-782; Ant. I192-1243; Tr. 734-812, 899-946; OC I586-I666), but quite a number do without and confine themselves to indirect representation of speech (El. 680-763; OT 1237-1285; Ant. 249-277, 404-440; Tr. 248-29o).

There is one more aspect of rhythm which is relevant to Sophocles: ellipsis (when an event is not recounted at all). In the first place, this plays a role - as everywhere in Greek literature - in the narration of events from the mythic past. Since - the main outline of - a story is 
well-known, it can be told allusively and elliptically. An example is the chorus' narrative of the attack of the Seven on Thebes: 'Beam of the sun, ..., you who made the man with the white shield who came from Argos in his panoply, go away in headlong flight with whistling bridle. Through the quarrelsome disputes of Polynices he was led forth against our land ...' (Ant. IO0-III). ${ }^{33}$ We do not hear that 'the man with the white shield who came from Argos' is Adrastus, that Polynices had come to him as a fugitive after his quarrel with his brother Eteocles, that he helped him because he is his son-in-law, and that the two brothers killed each other because of a curse from their father Oedipus. Strictly speaking, we should distinguish in cases like these between the elliptic narration by the intradramatic narrators, the chorus, for whom the events actually belong to the recent past, of which they themselves are a part, and who perhaps can therefore dispense with all kind of details, and the elliptic presentation by Sophocles, who can count on his spectators to fill in the details on the basis of their foreknowledge. Of course, intradramatic narrators can also leave out certain events deliberately, as does Clytemnestra in Electra 534-546: when discussing the sacrifice of Iphigeneia, she leaves out the reason why Agamemnon sacrificed his daughter (to appease Artemis after angering her by killing a stag and boasting about it), and offers other, less persuasive motives instead (for the sake of the army or his brother Menelaus). In her reaction Electra fills in emphatically the gap left by her mother: 'Ask the huntress Artemis what sin she was punishing when she held in check those many winds at Aulis; or I will tell you, since we may not lawfully learn from her' $(563-565)$.

The ellipses in mythological narratives are never marked. This is different in the other type of ellipsis, when characters, mainly messengers, avow explicitly that they have not been able to watch a certain event and hence have to leave a blank in their story. Thus Tecmessa, reporting Ajax' mad behaviour, says halfway her story: 'he sped off. What happened there (outside the tent, on the plain) I cannot tell you, but he came into the tent (again) bringing with him ...' (Aj. 294-296); or the messenger reporting Oedipus' death ends his story with a blank: 'But by what death that man perished, none among mortals could tell but Theseus. For no fiery thunderbolt of the god made away with him, nor any whirlwind rising from the sea at that time, but either some escort

\footnotetext{
33 Cf. also $S A G \mathcal{N}$ i:26o.
} 
from the gods or the unlighted foundation of the earth that belongs

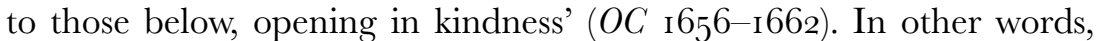
what we see is that Sophocles effectively exploits the restricted knowledge or understanding which internal narrators, generally speaking, have. We do not find similar explicit gaps in Aeschylean or Euripidean messenger-speeches, and it seems characteristic of Sophocles' interest in - the limits of - human perception and understanding to make his messengers, whose main function is to give an eyewitness report, defective. $^{34}$

\section{Frequency (repeating narration)}

Just as most of Sophocles' continuous narratives are told chronologically, they are also singulative: each event is recounted once. Occasionally, he may effectively employ iterative narration, when characters recount their way of life during a long period, as does Philoctetes: 'So one period of time after another went by for me, and I had to provide for myself under this poor roof. My stomach's needs this bow found for me ... And if I had to get some drink also or perhaps to cut some wood ..., I would struggle along and manage it', etc. (Ph. 285-316). Since Philoctetes clearly abhorred this way of life, the iterative narration in itself underscores the recurrent hardship of his life. ${ }^{35}$

Sophocles is particularly fond of repeating narration: the same events are told more than once, examples of which we have already come across in the discussion of retrospective narrative. The most obvious use of this form of narration is to present and contrast the focalization by different characters. The fight over Deanira by Achelous and Heracles is first presented briefly by the bride herself (Tr. 6-26), who speaks of Heracles in glorious terms, ascribes the victory of the son of Zeus to Zeus, but otherwise gives no details, because she was too terrified to watch. These details are later provided by the chorus (503-530), who explicitly motivate their ability to do so, and now ascribe Heracles' vic-

34 Other examples: OT I25I-I254; Ant. 249-252; (outside messenger-speech) Tr. 2 I23. For a full analysis of the gaps in the messenger-speech of Oedipus Tyrannus see Barrett 2002: $190-222$.

35 Other examples: El. 86-Io2 (Electra's repeated lamenting); $O C$ 345-352 (Antigone's life as exile with her father). Iterative narration may also create a summary, as in Electra 688-697 ('of the contests that the judges proclaimed, he won all the prizes, and was cheered for his victories'). 
tory to - the arbitration of - Aphrodite. Both the details of the struggle and the role of Aphrodite make their narrative applicable to Iole, too, who has just before entered the stage and whose fate- she was won by Heracles after a fight and as the result of his desire- has just been revealed. Thus, Sophocles' sure touch has reserved the full story for this point in his drama, where the confrontation between the two women, Deanira and Iole, is about to reach its tragic climax. ${ }^{36}$

Another use of repeating narration is the combination of the anticipation of an event in the form of a prospective narrative and the report of its execution or fulfillment in the form of a retrospective narrative. Thus, the poisoning of Heracles is first fearfully and remorsefully anticipated by Deanira (712-718), then reported as effected by an angry and vindictive Hyllus, who acts as a messenger (749-8I2), and finally reflected on once more by the chorus in $82 \mathrm{I}-840{ }^{37}$

\section{Conclusion}

Narratives are frequent and highly important in Sophocles' plays. His retrospective narratives are both internal and external, whereas his prospective narratives are-largely-internal, which means that the future outside the plays is not narrated but only briefly alluded to. External retrospective narratives fill in the prehistory of the plot, often in several, not necessarily chronologically ordered instalments, while internal retrospective narratives report offstage events. Internal prospective narratives anticipate developments of the plot, either correctly (when seers speak) or misleadingly (when a deceiving plot is being hatched) or ambiguously (dreams).

Whereas the larger continuous narratives, mainly messengerspeeches, display a chronological order, other narratives and especially dialogical ones often turn to anachronical orders, such as epic regres-

${ }^{36}$ Cf. Gellie 1972: 634; Heiden I989: 21-30 and 78; and C. Kraus i991: 79-82 and 86-88. Other examples are Ajax $719^{-} 734^{+} 74^{8-783}$ and $795^{-802}$, where the messenger first tells his news about Teucer to the chorus, then, briefly, to Tecmessa; Tr. II4-I42, where Hyllus repeats the story of Deanira's death, told in $863-946$ by the nurse, to Heracles; Ph. 4-II and 264-275 (the Greeks leaving behind Philoctetes); $O C$ 365-384 and $\mathrm{I} 29 \mathrm{I}^{-} \mathrm{I} 307$, where the quarrel between Polynices and Eteocles is first reported by Ismene, who condemns (and pities) the two, then presented once more by Polynices himself, who feels he has a legitimate case.

37 Another example is Antigone ro64-1086 (Tiresias announces Haemon's death) and II92-I243 (a messenger reports it). 
sion. Longer narratives vary in rhythm, modulating between summary (to speed up or paint a general picture) and scene (for climactic events). Narratives concerning the mythic past may completely leave out certain events, whereby the spectators are supposed to fill in the gaps on the basis of their prior knowledge. While these instances of ellipsis remain implicit, Sophoclean messengers explicitly call attention to gaps in their narratives.

All in all, Sophocles' use of time in his narratives is designed to serve his general interest in the theme of mortals coming to terms with the vicissitudes of their lives and the ways in which the past encroaches on the present. 